\title{
Numerical Modelling for the Extreme Flood Event in the Fitzroy Basin, Queensland, Australia
}

\author{
Md. Sharif Imam Ibne Amir, Mohammad Masud Kamal Khan, Mohammad Golam Rasul, \\ Raj H. Sharma, and Fatema Akram
}

\begin{abstract}
Fitzroy Basin is the second largest catchment that drains to the coast in Australia. Fitzroy Basin is capable of producing severe flooding from tropical cyclone with heavy rainfall due its immense size and fan-like shape. Analysis shows that the historical peaks of different tributaries in different sub-basins of the Fitzroy River occurred in different years and their contributions are different for each flood event. However a scenario might happen when the flood peaks of different tributaries would synchronize and its consequence will be mass devastation indeed. The impact of combination of extreme flood peaks of different tributaries in different sub-basins to the total flood magnitude of the Fitzroy river is presented in this study using an integrated hydrological and hydrodynamic model. The discharge found from the synchronized extreme flood event was about $36 \%$ higher than the most severe historical flood that occurred in 1918.
\end{abstract}

Index Terms-Basin, hydraulic model, hydrological model, MIKE 11.

\section{INTRODUCTION}

Flooding from storm event is one of the major natural disasters in many counties of the world [1], [2]. The Fitzroy river, which passes through the Rockhampton city, has a long history of flooding. Notable major floods occurred in Rockhampton in 1918, 1954, 1988, 1991 and 2011 of which the worst one happened in 1918 [3]. In the recent flood in 2011, there was significant loss of lives, properties, livestocks and crops, as well as extensive damage occurred to dwelling, road, rail and air links in Rockhampton and surrounding areas [4].

There are four major upstream rivers Isaac-Connors, Nogoa, Comet, and Dawson and one downstream river Mackenzie. All of these upstream and downstream rivers pass through the Fitzroy river. The Fitzroy river floodplain has narrowed by hills in the reach from where Mackenzie and Dawson rivers join to form the Fitzroy to downstream of the Gap gauge station. For the available insufficient opening, the upstream and downstream flood water takes time to come to the Fitzroy river in Rockhampton region. In 1988 flood happened due to heavy rainfall occurred from the tropical Cyclone 'Charlie', in the Connors-Issac sub-catchment, which comprises only $16 \%$ of the Fitzroy basin. The rainfall in other sub-basins was limited in that time. In 1918 and 2011,

Manuscript received January 16, 2013; revised March 28, 2013.

M. S. I. I. Amir and F. Akram are with the Centre for Plant and Water Science, Central Queensland University, Rockhampton, QLD 4702, Australia (e-mail: m.amir@cqu.edu.au, f.akram@cqu.edu.au).

M. M. K. Khan, M. G. Rasul, and R. H. Sharma are with the School of Engineering and Technology, Central Queensland University, Rockhampton, QLD 4702, Australia (e-mail: m.khan@cqu.edu.au, m.rasul@cqu.edu.au, r.sharma@cqu.edu.au). heavy rainfall occurred in Fitzroy and Issac sub-basins which caused major flooding in Fitzroy river. Similarly in 1954, the Fitzroy river observed major flooding due to heavy rainfall in the Nogoa sub-basin. So, high flow from upstream and downstream rivers which passes through the Fitzroy river is the main reason of the severe flooding in the Fitzroy river in the Rockhampton area.

The analysis of the hydrological records show that none of the previous single flood event occurred simultaneously in all sub-catchments with peak flows. But there is a possibility that the flood peaks of different tributaries would synchronize. Australia is significantly vulnerable to climate change expected over the next 100 years [5]. Extreme weather events like flood will be more extreme or and more frequent owing to climate change [6]. Therefore there is a possibility when extreme runoff may discharge from all of these sub-catchments at the same time due to the greater uncertainty and propensity towards extreme climate change, making the Fitzroy floods catastrophic. It would be unwise to ignore and be unprepared for such an extreme event.

Numerical hydrological and hydraulic (hydrodynamic) models have been used now a days for the flood studies [7]. The hydrologic model calculates the runoff generated from rainfall occurred in the area along with other parameters using historical rainfall and evaporation time series data. The output of hydrological model is used as input of hydraulic model. The most important tool for the assessment of flood flow of the river is hydraulic modelling [8]-[9]. It is important to use a reliable hydraulic flood model which provides an accurate estimation of flood hazards [10]-[11].

The main objective of this study was to analyze the extreme catastrophic flood event from the extreme runoff for all sub-catchments. We choose the integrated hydrologic and hydraulic modelling package MIKE 11 because of its flexibility, speed, accuracy and popularity for the flood studies [12]. A short description of the study area is presented in the next section, followed by the genesis of previous extreme floods in the Fitzroy Basin. The description of the data sets and model, performance of the model are provided in the section 'Data and Model'. The model results and discussions are presented in the last section.

\section{StUdy AREA}

The Fitzroy basin (Fig. 1) is located in the east part of Queensland, Australia and it is the second largest catchment that drains to the coast in Australia. The Fitzroy river catchment covers an area of $144,000 \mathrm{~km}^{2}$ [4]. Land, water resources, agriculture, coal and mining industries and marine tourism make this catchment an important location in 
Australia [4]. The total population of this Basin is about 200,000 people and major towns are Rockhampton and Emerald.

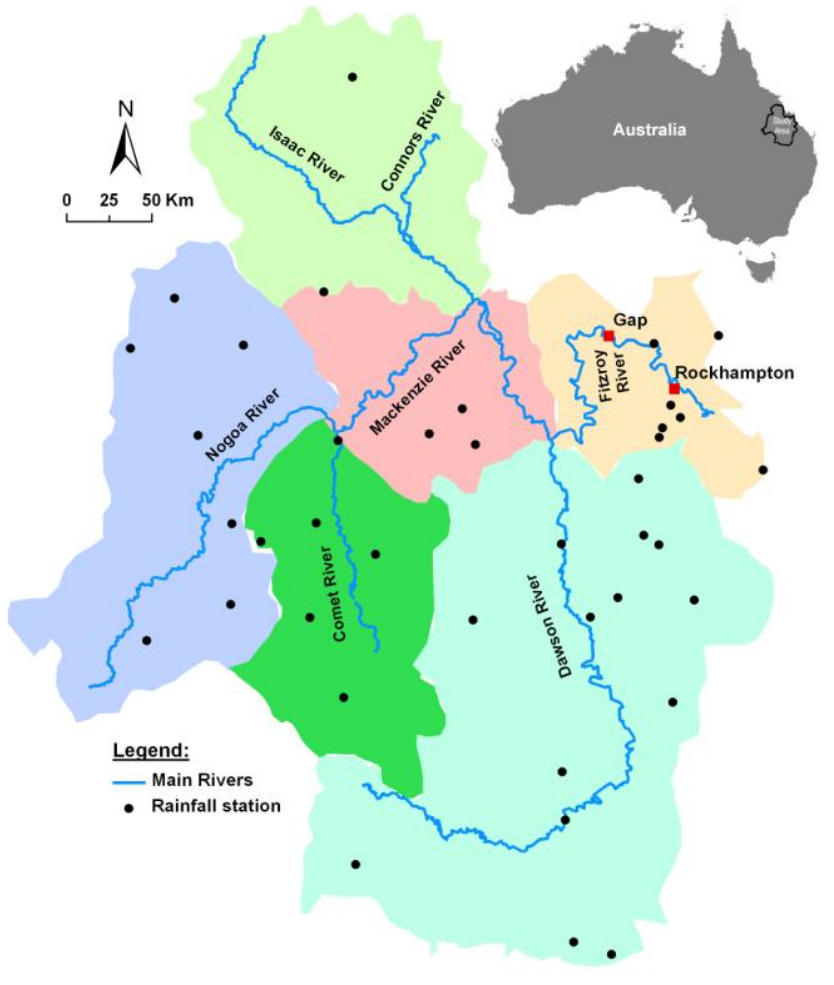

Fig. 1. Study Area.

TABLE I: DETAILS OF SUB-CATCHMENT OF FITZROY BASIN

\begin{tabular}{llcc}
\hline $\begin{array}{l}\text { Sub-catchment } \\
\text { Sub-Basin) }\end{array}$ & Major river(s) & $\begin{array}{c}\text { Catchment } \\
\text { area }\left(\mathrm{km}^{2}\right)\end{array}$ & $\begin{array}{c}\% \text { of } \\
\text { Catchmen }\end{array}$ \\
\hline Isaac & Isaac, Connors & 22,869 & 16 \\
Nogoa & Nogoa & 27,714 & 19 \\
Comet & Comet & 17,811 & 12 \\
Mackenzie & Mackenzie & 13,449 & 9 \\
& Isaac, Connors, Nogoa, & 81,843 & 56 \\
Mackenzie (total) & Comet, Mackenzie & & 36 \\
& Dawson & 51,588 & 8 \\
Dawson & Fitzroy & 11,039 & 100 \\
Fitzroy & Isaac, Connors, Nogoa, & & \\
& Comet, Mackenzie, & 144,470 & \\
Fitzroy (total) & Dawson, Fitzroy & & \\
& &
\end{tabular}

The Fitzroy Basin consists of six sub-catchments and each sub-catchment has one major river. The sub-catchment area and percentage of total catchment is presented in Table I. The four upstream major tributary rivers: Connors-Issac, Nagoa, Comet, and Mackenzie and one downstream tributary river Dawson combinedly form the Fitzroy river. Nagoa River, which is in the far west of the catchment, starts to flow through Emerald and joins with the Comet River. The combined flow of these two separate rivers passes through the Mackenzie River. The Connors River, which is situated in the northern part of the catchment, flows through the Issac at Yatton. The Connors-Issac river system joins with the Mackenzie River just upstream of Tartrus weir. The downstream river Dawson joins with the Mackenzie. The combined stream then known as the Fitzroy passes through Rockhampton and into the Keppel Bay which is $60 \mathrm{~km}$ downstream of Rockhampton. Large volume of flood runoff created by the heavy rainfall occurring anywhere in the basin can produce flood in the Fitzroy river in the Rockhampton region.

\section{GENESIS OF PAST HistoricAl FLOODS}

The Fitzroy River has a long history of flooding. These past floods originated from different sub-catchments following heavy rain depressions associated with cyclonic influences on the catchment area. Generally floods occurred between the months January to March. Due to the large size of the catchment, flooding does not occur at once with cyclonic influences; rather it takes some time to generate. Fitzroy river flood history is presented in the Table II. Table II shows that major floods resulted either from the Fitzroy or Issac or Nogoa river and the supplementary floods come from Dawson river. Each of the major river systems has had major floods in the past. The table also presents that around 8-11 days are required to get peak flood in Fitzroy river after occurring maximum rainfall in other sub-basins.

TABLE II: GENESIS OF PAST EXTREME FLOODS OF FITZROY RIVER

\begin{tabular}{|c|c|c|c|c|c|}
\hline \multirow{2}{*}{$\begin{array}{l}\text { Flood } \\
\text { Year }\end{array}$} & \multicolumn{2}{|c|}{$\begin{array}{l}\text { Main contributing } \\
\text { sub-basins }\end{array}$} & \multirow{2}{*}{$\begin{array}{l}\text { Other } \\
\text { Contributing } \\
\text { sub-basins }\end{array}$} & \multicolumn{2}{|c|}{$\begin{array}{l}\text { Rockhampton flood } \\
\text { gauge }\end{array}$} \\
\hline & Name & $\begin{array}{l}\text { Date of } \\
\text { Peak } \\
\text { Rainfall }\end{array}$ & & $\begin{array}{l}\text { Maximum } \\
\text { flood } \\
\text { level }(\mathrm{m})\end{array}$ & $\begin{array}{l}\text { Date of } \\
\text { Peak } \\
\text { Flood }\end{array}$ \\
\hline 1918 & $\begin{array}{l}\text { Fitzroy, } \\
\text { Isaac }\end{array}$ & 21-23 Jan & Nogoa, Comet & 10.11 & $1 \mathrm{Feb}$ \\
\hline 1954 & Nogoa & 1-9 Feb & $\begin{array}{l}\text { Dawson, Fitzroy, } \\
\text { Comet, Isaac }\end{array}$ & 9.4 & $19 \mathrm{Feb}$ \\
\hline 1988 & Isaac & 1-2 Mar & - & 8.4 & $11 \mathrm{Mar}$ \\
\hline 1991 & Fitzroy & $\begin{array}{l}28-31 \\
\text { Dec } 1990\end{array}$ & Isaac, Dawson & 9.3 & $12 \mathrm{Jan}$ \\
\hline 2011 & $\begin{array}{l}\text { Fitzroy, } \\
\text { Isaac }\end{array}$ & 25-28 Jan & Comet, Nogoa & 9.2 & 4 Jan \\
\hline
\end{tabular}

Major Fitzroy floods vary by the pattern of severe rainfall in the upstream or downstream sub-basins. The highest recorded flood event occurred in Rockhampton in 1918 due to heavy rain associated with a severe tropical cyclone. A severe rainfall happened in the Fitzroy and Isaac sub-catchments in that time. The total January rainfall was $910.2 \mathrm{~mm}$ in the Fitzroy sub-basin and $720.6 \mathrm{~mm}$ in the Isaac sub-basin respectively. The 3 day (21-23 January) rainfall was $611.1 \mathrm{~mm}$ in the Fitzroy sub-basin. Prior to the heavy rainfall in the Fitzroy and Isaac sub-basin, the Fitzroy River at Rockhampton was already wet due to minor flooding in the Nogoa and Comet sub-basins. At the Rockhampton flood gauge the highest recorded flood was $10.11 \mathrm{~m}$ (8.65m AHD) which occurred in $1^{\text {st }}$ February 1918.

The second highest recorded peak in Rockhampton occurred in 1954 due to the heavy rainfall in the Nogoa sub-basin. The total February rainfall in this sub-basin was $712.2 \mathrm{~mm}$ and most of the rainfall happened over a period from 5 to 13 February. The other contributing sub-basins for this flood event were the Dawson, Fitzroy, Comet and Isaac. The maximum flood level of $9.40 \mathrm{~m}$ (7.952m AHD) was 
recorded on $19^{\text {th }}$ February at the Rockhampton flood gauge.

The third largest flood event in 1991 happened in Rockhampton due to the tropical cyclone 'Joy' associated with a heavy rainfall in the Fitzroy sub-basin. High volume of rainfall $(650 \mathrm{~mm})$ was observed in this sub-basin during 28-31 December 1990. Besides, 528.6mm rainfall was recorded over a period from 27 to 31 December 1990 in the Isaac sub-basin. Other minor rainfall was observed in the Dawson sub - basin. All of the rainfall made a flood peak of $9.30 \mathrm{~m}\left(7.852 \mathrm{~m}\right.$ AHD) on $12^{\text {th }}$ January 1991 at the Rockhampton flood gauge.

The most recent and fourth highest flood event happened in 2011. The main contributing sub-basins for this flood were the Fitzroy and Isaac. The total January rainfall was $523 \mathrm{~mm}$, $543 \mathrm{~mm}, 441.6 \mathrm{~mm}$ and $386.4 \mathrm{~mm}$ in the Fitzroy, Issac, Comet and Nogoa sub-basin respectively. The 4 day (25-28 January) rainfall was $281.8 \mathrm{~mm}$ in the Fitzroy sub-basins.

\section{DATA AND MODEL}

\section{A. Data}

Data are prerequisite for reliable model setup and model results and to have an understanding of the existing physical processes. Several types of data were used for hydrological and hydraulic modelling purposes. Topographic data were used for the study area map preparation and hydraulic model set up. The topographic data consists of several data layers including waterbodies, road transport, rail transport, localities and built up area. Historical time series rainfall and evaporation data were used for the hydrological rainfall runoff model set up. Historical time series stream flow and stream water level data were used for the hydraulic model set up, calibration and validation. Besides, the river cross section data were used for hydraulic model set up.

\section{B. Model Description}

A brief description of the MIKE 11 modelling system has been presented in this section because a certain level of familiarity is important to understand the described modelling work. The following two modules of MIKE 11 have been used for this study.

- MIKE 11 NAM (Rainfall Runoff Module)

- MIKE 11 Hydrodynamic (HD)

MIKE 11 NAM is a rainfall-runoff module of MIKE 11 river modelling system. It is a lumped conceptual hydrological model that simulates the rainfall-runoff processes occurring in a single sub-basin or several sub-basins in a river Basin. It can be applied independently or used to represent one or more contributing sub-basins that generate lateral inflows to a river network.

MIKE $11 \mathrm{HD}$ is a comprehensive one dimensional river modelling package developed by the Danish Hydraulic Institute in 1987 [13]. This modelling system has been used in numerous engineering studies around the world [14] for unsteady flow. Modelling of unsteady flow is based on three fundamental elements, i.e. a differential relationship expressing the physical laws, a finite difference scheme producing a system of algebraic equations, an algorithm to solve these equations. The governing equation of this model solves the vertically integrated equations of conservation of mass (Equation 1) and momentum (Equation 2), which are the Saint Venant equation [15].

$$
\begin{gathered}
\frac{\partial A}{\partial t}+\frac{\partial Q}{\partial x}=q \\
\frac{\partial Q}{\partial t}+\frac{\partial}{\partial x}\left(\frac{\alpha Q^{2}}{A}\right)+g A \frac{\partial h}{\partial x}+\frac{g Q|Q|}{C^{2} A R}=0
\end{gathered}
$$

where $C=$ Chezy's resistance coefficient, $R=$ hydraulic or resistance radius, $Q=$ discharge, $A=$ flow area, $q=$ lateral flow, $h=$ water level above datum, $\alpha=$ momentum distribution coefficient

The solution of the Saint Venant equation is based on the implicit finite difference scheme developed by Abbott and Ionescu [16]. The transformations of governing equations into a set of implicit finite difference equations is performed in a computational grid consisting of alternating points of the discharge $(Q)$ and water level $(h)$ and are computed at each time step.

\section{Model Setup, Calibration and Validation}

The main objective of this study was to identify the extreme flood event of Fitzroy river. The extreme flood event has been defined in a way when all the sub-basins will produce the historical severe rainfall at a time. Before simulation of such a scenario, an integrated hydrological and hydraulic model was calibrated and validated for historical flood events using MIKE 11 NAM and MIKE 11 HD module. The computation time step was used as 1 hour.

Model calibration is very important as it provides not only the realistic representation of the physical system but also the reliability and confidence on model results. To represent the current floodplain condition, the model was calibrated for the last two most significant extreme flood events 2011 and 1991. The calibrated model was validated for the 1988 flood event. Due to missing records the model was not validated for the 1918 and 1954 flood event. After the successful calibration and validation of MIKE 11 NAM model, it was connected to the MIKE $11 \mathrm{HD}$ model. The lateral contributions from the sub-basins were calculated by the NAM model using mean areal rainfall and propagation of flood runoff along the reach was calculated by the HD model. All upstream and downstream ends of unconnected part are known as model boundaries. In this study, four upstream and one downstream unconnected part are defined by the time series of discharge and water level respectively.

\section{Model Performance}

The performance of the model was evaluated using Nash-Sutcliffe coeffient ( $E_{\mathrm{NS}}$ [17] and index of agreement $(\mathrm{d})$ [18] indices as represented by the Equation (3) and (4).

$$
\begin{gathered}
E_{N S}=1-\frac{\sum_{i=1}^{n}\left(O_{i}-S_{i}\right)^{2}}{\sum_{i=1}^{n}\left(O_{i}-\bar{O}\right)^{2}} \\
d=1.0-\frac{\sum_{i=1}^{n}\left(O_{i}-S_{i}\right)^{2}}{\sum_{i=1}^{n}\left(\left|O_{i}-\bar{O}\right|+\left|S_{i}-\bar{O}\right|\right)^{2}}
\end{gathered}
$$

where $\mathrm{O}=$ observed value, $\mathrm{S}=$ simulated value and $\overline{\mathrm{O}}=$ mean 
of the observed values.

\section{RESULTS AND DISCUSSION}

Nine important calibration parameters of the hydrological model, MIKE 11 NAM, were identified in different sub-basins by calibration and validation of the model. On the other hand, the only calibration parameter of the MIKE 11 HD model is Manning's roughness (M) whose value was found to be 20-60 for this study.

A comparison of simulated and measured values of stream flow for the year 1988, 1991 and 2011 at the Gap gauge location is presented in Table III to show the performance of the model. The table shows that the measured and simulated values of stream flow for 1988, 1991 and 2011 are very close.

TABLE III: COMPARISON OF MEASURED AND SIMULATED STREAM FLOW AT GAP GAUGE LOCATION

\begin{tabular}{c|c|c|c}
\hline \hline \multirow{2}{*}{ Event } & \multicolumn{2}{|c|}{ Stream flow, Q $\left(\mathrm{m}^{3} / \mathrm{s}\right)$ at the Gap gauge location } & \multirow{2}{*}{$\%$ of difference } \\
\cline { 2 - 3 } & Measured & Simulated & \\
\hline 1988 & 9,663 & 9,805 & +1.47 \\
1991 & 14,549 & 14,814 & +1.82 \\
2011 & 13,274 & 13,353 & +0.6 \\
\hline
\end{tabular}

Moreover comparison plots of simulated and measured values of the stream water level at the Gap station is presented in Fig. 2 that shows a good agreement between observed and simulated data.

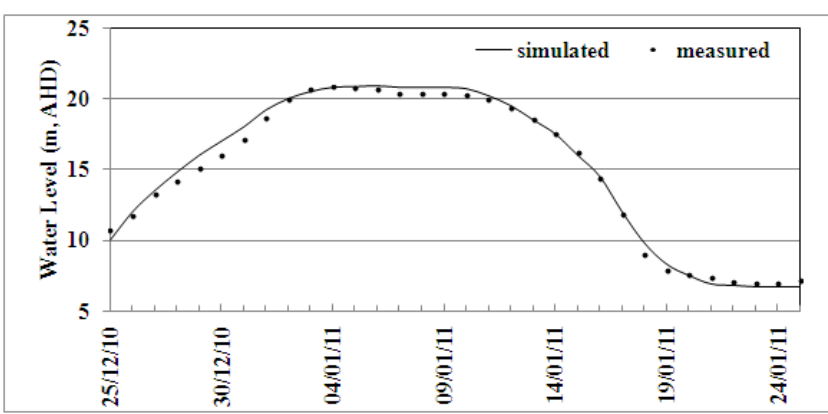

Fig. 2. Daily stream water level at Gap station for 2011 flood event.

Besides, the Goodness of Fit indices, Nash-Sutcliffe coefficient $\left(\mathrm{E}_{\mathrm{NS}}\right)$ and index of agreement $(\mathrm{d})$ were calculated for the calibration and validation period at Gap station to get the model performance. These values are presented in Table IV which shows that the model performance is quite good.

TABLE IV: VALUES OF GOODNESS-OF-FIT INDICES AT GAP GAUGE LOCATION

\begin{tabular}{ccc}
\hline \hline Year & $\mathrm{E}_{\mathrm{NS}}$ & $\mathrm{d}$ \\
\hline 2011 (calibration period) & 0.844 & 0.953 \\
1991 (calibration period) & 0.826 & 0.921 \\
2008 (validation period) & 0.812 & 0.932 \\
\hline \hline
\end{tabular}

To get the extreme flood event, a scenario was generated on the above calibrated MIKE 11 NAM model where one input, mean aerial rainfall, was replaced by the maximum rainfall from the entire flood event. The other model parameters for NAM and HD module were kept as it is. The annual peak stream flow at the Gap gauge location was calculated for the extreme flood event. The simulated discharge at Gap station was $24212 \mathrm{~m}^{3} / \mathrm{s}$. This simulated value has been compared with the measured stream flow values of the different flood year and the result is presented in Table V. The measured maximum discharge at the Yaamba station in 1918 was $17757 \mathrm{~m}^{3} / \mathrm{s}$, which is located $33.5 \mathrm{~km}$ downstream of the Gap station. As there was no record of discharge at the Gap station, for the most severe flood event in 1918, the record of the Yaamba station has been used to compare with the extreme event discharge. This simulated discharge is $36 \%$ higher than the 1918 maximum flood event.

TABLE V: COMPARISON OF MEASURED AND EXTREME STREAM FLOW AT GAP GAUGE LOCATION

\begin{tabular}{|c|c|c|c|}
\hline \multicolumn{2}{|c|}{$\begin{array}{l}\text { Historical maximum } \\
\text { stream flow (Q) at the Gap } \\
\text { gauge location }\end{array}$} & \multirow{2}{*}{$\begin{array}{l}\text { Extreme stream flow } \\
(\mathrm{Q}) \text { at the Gap gauge } \\
\text { location }\end{array}$} & \multirow{2}{*}{$\begin{array}{l}\% \text { of higher } \\
\text { than historical } \\
\text { maximum }\end{array}$} \\
\hline Event & $\mathrm{Q}\left(\mathrm{m}^{3} / \mathrm{s}\right)$ & & \\
\hline 1918 & 17,757 & \multirow{5}{*}{24,212} & 36 \\
\hline 1954 & 14,606 & & 66 \\
\hline 1988 & 9,663 & & 151 \\
\hline 1991 & 14,549 & & 66 \\
\hline 2011 & 13,274 & & 82 \\
\hline
\end{tabular}

\section{ACKNOWLEDGMENT}

The author gratefully acknowledges the Geoscience Australia for the GIS data and Bureau of Meteorology, Australia for the time series rainfall and evaporation data sets, Department of Environment and Resource Management, Australia for the historical stream flow, height and cross section data sets and Department of Transport and Main Roads, Queensland, Australia for the tidal data.

\section{REFERENCES}

[1] B. B. Campion and J. Venzke. (February 2013). Rainfall variability, floods and adaptations of the urban poor to flooding in Kumasi, Ghana. Natural Hazards [Online]. 65(3). pp. 1895-1911. Available: http://link.springer.com/article/10.1007\%2Fs11069-012-0452-6?LI=tr ue\#

[2] M. Masood and K. Takeuchi. (March 2012). Assessment of flood hazard, vulnerability and risk of mid-eastern Dhaka using DEM and 1D hydrodynamic model. Natural Hazards [Online]. 61(2). pp. 757-770. Available:

http://link.springer.com/article/10.1007\%2Fs11069-011-0060-x?LI=tr ue\#

[3] Planning Scheme for the city of Rockhampton, in Rockhampton City Plan 2005 (Chapter 6), Rockhampton Regional Council, 2009.

[4] M. S. I. I. Amir, M. M. K. Khan, M. G. Rasul, R. H. Sharma, and F. Akram, "Rainfall, Temperature and Evaporation Trends in the Fitzroy Basin, Queensland, Australia," in $34^{\text {th }}$ Hydrology and Water Resources Symposium, Sydney, Australia, November 19-22, 2012. pp. 1484-1491.

[5] J. J. McCarthy, O. F. Canziani, N. A. Leary, D. J. Dokken, and K. S. White. (Eds.). Climate change 2001: impacts, adaptation, and vulnerability: contribution of Working Group II to the third assessment report of the Intergovernmental Panel on Climate Change. Cambridge University Press. 2001.

[6] IPCC (Inter government panel on climate change), 2007, Fourth Assessment Report of the IPCC [Solomon, S., Qin, D., et al. (eds.)], Cambridge University Press, Cambridge, United Kingdom and New York, NY, USA.

[7] F. Pappenberger, K. Beven, M. Horritt and S. Blazkova. (February 2005). Uncertainty in the calibration of effective roughness parameters in HEC-RAS using inundation and downstream level observations. Journal of Hydrology [Online]. 302(1). pp. 46-69. Available: http://www.sciencedirect.com/science/article/pii/S0022169404003294

[8] N. M. Hunter, P. D. Bates, M. S. Horritt and M. D. Wilson. (October 2007). Simple spatially-distributed models for predicting flood 
inundation: a review. Geomorphology [Online]. 90(3). pp. 208-225. Available:

http://www.sciencedirect.com/science/article/pii/S0169555X0700130 4

[9] G. Pender and S. Néelz. (2007). Use of computer models of flood inundation to facilitate communication in flood risk management Environmental Hazard [Online]. 7(2). pp. 106-114. Available: http://www.sciencedirect.com/science/article/pii/S1747789107000191

[10] J. Ballesteros, J. Bodoque, A. Díez-Herrero, M. Sanchez-Silva and M. Stoffel. (June 2011). Calibration of floodplain roughness and estimation of flood discharge based on tree-ring evidence and hydraulic modelling. Journal of Hydrology [Online]. 403(1). pp. 103-115.

Available: http://www.sciencedirect.com/science/article/pii/S0022169411002253

[11] J. L. de Kok and M. Grossmann. (January 2010). Large-scale assessment of flood risk and the effects of mitigation measures along the Elbe River. Natural hazards [online]. 52(1). pp. 143-166. Available: http://link.springer.com/article/10.1007\%2Fs11069-009-9363-6?LI=tr ue

[12] G. N.Wijesekara, A. Gupta, C. Valeo, J. G. Hasbani, Y. Qiao, P. Delaney and D. J. Marceau. (January 2012). Assessing the impact of future land-use changes on hydrological processes in the Elbow River watershed in southern Alberta, Canada, Journal of Hydrology [Online]. article in press. Available: http://www.sciencedirect.com/science/article/pii/S0022169411002587

[13] Reference Manual: A modelling system for Rivers and Channels. Danish Hydraulic Institute, Denmark.

[14] User Guide: A modelling system for Rivers and Channels. Danish Hydraulic Institute, Denmark

[15] V. T. Chow, Open-channel Hydraulics, McGraw-Hill, New York, 1959.

[16] M. Abbott, H. Petersen and O. Skovgaard. (1978). On the numerical modelling of short waves in shallow water. Journal of Hydraulic Research [Online]. 16(3). pp. 173-204. Available: http://www.tandfonline.com/doi/abs/10.1080/00221687809499616

[17] J. E. Nash and J. V. Sutcliffe. (April 1970). River flow forecasting through conceptual models part I - A discussion of principles. Journal of Hydrology [Online]. 10(3). pp. 282-290. Available: http://www.sciencedirect.com/science/article/pii/0022169470902556

[18] C. J. Willmott, "On the validation of models," Physical geography, vol. 2. pp. $184-194,1981$

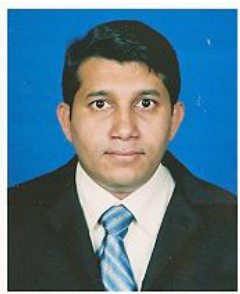

M. Sharif I. I. Amir was born in Bangladesh. He received the M.Sc. degree in Water Resources Development from Bangladesh University of Engineering \& Technology (BUET), Dhaka, Bangladesh, and B.Sc. Eng. (hons.) degree in Water Resources Engineering from the same University.

He has eight years of professional experience in the field of Water Resources Engineering. His technical expertise includes hydrological analysis; river hydraulics; river morphology; hydraulic design of cross drainage structure; hydrological and morpholog ical data collection, processing and analysis. He worked in several projects categorized as integrated water resources management, tidal river management, flood and drainage study, drainage design, morphological study and climate change impact on basin level. He has developed, calibrated and validated several flood, drainage, sediment transport, salinity and heat dispersion model for different client based assignments. Currently he is working towards $\mathrm{PhD}$ degree at Central Queensland University, Rockhampton, Australia. He has six publications in the area of river management.

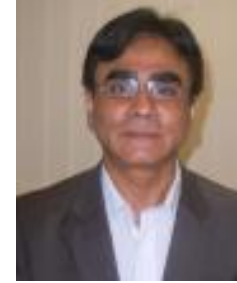

M. Masud K. Khan is employed by the Central Queensland University since 1990 and is currently a Professor in the School of Engineering and Technology. He received his MS from Moscow Institute of Petrochemical and Gas Industry in 1982. Subsequently he worked with the oil industry for 2 years. He then returned to a full-time $\mathrm{PhD}$ study, at the University of Sydney, which was awarded in 1990.

His research and teaching interests are in the area of fluid mechanics, rheology and sustainable energy technologies. He has a long history of working on industry collaborated projects and his works are well recognised both nationally and internationally. He has published over 185 research papers in journals and conferences including 5 book chapters and has spent three visiting professorial positions in the US and Canada working of various research projects. He is a member of the Institute of Engineers, Australia and an executive member of the Australian Society of Rheology (ASR).

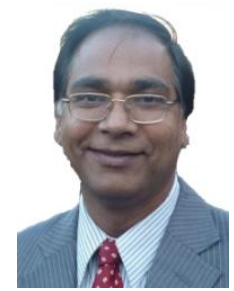

Mohammad G. Rasul was born in Bangladesh. He obtained his $\mathrm{PhD}$ in the area of energy, environment and thermodynamics from University of Queensland, Australia, in 1996. He received his Master of Engineering in energy technology from Asian Institute of Technology, Bangkok, Thailand, in 1990.

Currently, he is an Associate Professor in School of Engineering and Technology at Central Queensland University, Australia. He has published more than 240 research articles/papers both in reputed journals and refereed conferences including 8 book chapters, 2 edited books and 1 research book, one awarded paper in a refereed journal and two awarded papers at conferences. He has secured more than \$2.5 million research grant. He is recognised in professional communities which he has demonstrated through creating significant impact and the large number of citations by the relevant professionals, both nationally and internationally. His publications have been attracted significant interest with 430 citations and h-index of 12 .

Associate Professor Rasul has also made significant contributions in engineering education research and scholarship. He has edited a book on Developments in Engineering Education Standards: Advanced Curriculum Innovations published by IGI Global publisher in USA. His contributions to the profession and national and international community have been demonstrated through his varied roles and activities, such as membership of national and international technical, scientific and advisory committees, membership of different professional organizations and various organizing committees. He has been leading and contributing to the strategic research on Resource Industries and Sustainability in the area of energy, environment and thermodynamics.

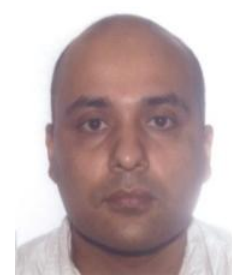

Raj H. Sharma received his B.E. and M.Sc. degrees from Tribhuvan University Nepal in 1999 and 2002 respectively and $\mathrm{PhD}$ degree from Kyoto University, Japan in 2006. He is working as a lecturer at School of Engineering and Technology, Central Queensland University, Australia from 2010. He was a Humboldt Fellow at TU Bergakademie Freiberg, Germany from 2007-2010. His research interests are flood, soil erosion and sediment transports.

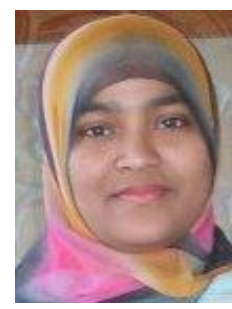

Fatema Akram was born in Bangladesh. She received both of the B.Sc. and M.Sc. degree in Water Resources Engineering from Bangladesh University of Engineering and Technology (BUET).

She has 7 years experience of working with Institute of Water Modelling (www.iwmbd.org). She has strong research interest in hydrologic and hydraulic modelling, groundwater modelling, water quality modelling, water resources assessment, sustainable water use, stormwater reuse and recycle techniques, geographic information systems etc. Currently she is working towards $\mathrm{PhD}$ degree at Central Queensland University, Rockhampton, Australia. She has two peer reviewed conference papers to her credit. 